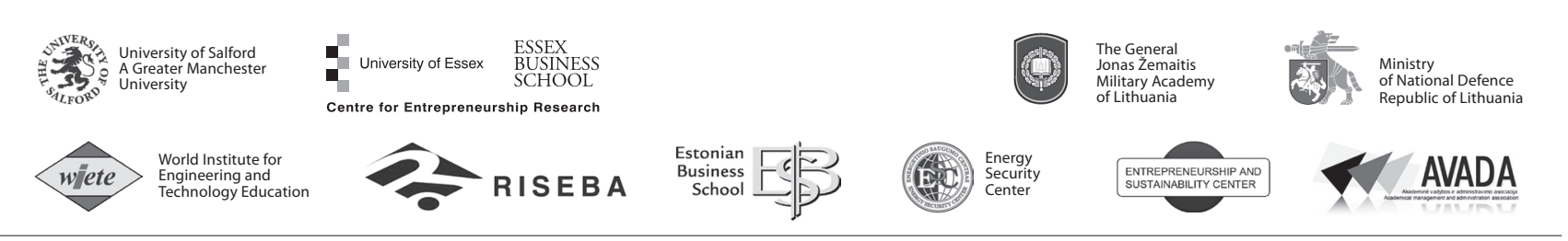

Journal of Security and Sustainability Issues www.lka.lt/index.php/lt/217049/

\author{
2011, 1(2): 113-121 \\ http://dx.doi.org/10.9770/jssi.2011.1.2(4)

\section{CRITICAL EMPLOYMENT ANALYSIS: THEORY, METHODOLOGY AND RESEARCH}

\author{
Mirjana Radović Marković \\ Institute of Economic Sciences, Zmaj Jovina 12, 11000 Belgrade, Serbia \\ E-mail:mradovic@gmail.com
}

Received 15 June 2011; accepted 10 October, 2011

\begin{abstract}
While labour market research is not a new phenomenon, interest in it is growing. Literature frequently discusses changes in the market as separate disciplines, isolated from each other. On the other hand, it can be found that more and more scientists understand and choose interdisciplinary research as a powerful tool for understanding, critique, explanation and change. But some of these approaches have difficulty accounting for change and the co- existence of similarity and diversity, as well as being 'gender blind'.

This article critically reviews a range of theoretical approaches to employment research and practice using the lens of feminism. The appropriate integration of gender awareness into mainstream theorizing, is advocated alongside its separate development. In addition, in this article we provide a multidisciplinary approach and attempt to integrate important aspects (knowledge, education, entrepreneurship, self-employment and informality, employment and globalization) that the analysis of labour market and research puts forward. In the light of this assessment, this paper sets out to indicate potentially useful approaches for conducting employment research in the future, where gender is a core component of analysis. Such approach aims to act as a catalyst to provoke a more extensive debate on this topic.
\end{abstract}

Keywords: Employment, Knowledge Society, Globalization and Gender Role, Gender Inequality, Informal Sector, Skills, Education.

Reference to this paper should be made as follows: Radović Marković, M. 2011. Critical employment analysis: theory, methodology and research, Journal of Security and Sustainability Issues 1(2): 113-121.

http://dx.doi.org/10.9770/jssi.2011.1.2(4)

JEL Classifications: H0, H4, I2, I24, J16, M10

\section{Introduction}

The purpose of this paper is to critically analyze the varieties of existing approaches towards the employment issues. The varieties of approaches differ in theory, methodology and research. Our own work in this area differs to some extent in these respects from some new research in the field of employment (Afgan and Carvalho, Natarajan, Nagan 2010) as with others that have partial theoretical approach to the topic. In our opinion, these researches, however thorough and well written, primarily lack certain important aspects that should absolutely be included into this analysis. It is, namely, necessary to pay special attention to new labour and education modalities that are the fundamentals of the "knowledge economy" as well as to the issues of educational curricula development in the field of entrepreneurship, meant to facilitate self-employment, the issues of closer connection of educational institutions with manufacturing and other types of organizations, the reduction of discrimination and achieving gender equality as one of the most important Millennium objectives, enhancing various types and forms of entrepreneurship activities with special emphasis on women' and social entrepreneurship, the importance of women entrepreneurship in poverty alleviation, the issues of global and virtual firms, e-learning, etc.

\section{Methodology}

In order to explore this large and complex field, a critical peer literature review was used. The peer lit- 
erature review helped us to identify gaps in the form of relevant questions that do not appear to have been tackled by the authors, making clear the focus of where further enquiry should be. Namely, the review aims to add value to the current state of knowledge by critically evaluating the existing literature on employment issues and providing a reflective stance on existing debates and findings.

\section{Debates on the Employment Issues}

We use review of the recently published literature as a means of showing that, although a lot of research has been done on the employment issues, especially little research has been done in gender employment analysis. There are also no research concepts based on integrated approach that connects the following important questions: a) Women's right to employment; b) Globalization and gender role; c) Gender inequality and entrepreneurship; d) Women and informal employment; e) Female Entrepreneurship development as an imperative in new economy; f) Education for Entrepreneurship and g) New modalities of knowledge delivery.

These important questions will be briefly dealt with in this article, if only to highlight their importance for a new economic theory and fostering a sustainable economic growth.

a) Women's right to employment. Having read the scientific articles written by Afgan and Carvalho (2010), Natarajan, Nagan (2010), we have come to a conclusion that we cannot talk about human rights and leave out the problem of women position in the society and their right to employment. This issue has to be paid special attention to, having in mind that the problem of discrimination both in employment of women labour force and in their promotion at work is still far from being solved. Namely, women who successfully join modern social flows in the new way were not fairly rewarded for their work, usually being paid less for their work than their male counterparts at the same job level. In other words, women earn on average $15 \%$ less than men in the EU. A similar problem is with the representation of women in leading positions (32\%) regardless of the fact that they, on average, are higher educated compared to men. Further confusion is seen in the fact that this percentage increased by $1 \%$ only in the last 5 years. In Germany, for example, women earn on average $22 \%$ per hour less than men. For this reason Germany is the EU country, with a maximum difference as regards the income between the genders. Only in Estonia, Cyprus and Slovakia women earn an income equally high or even higher than men. The reason for such large differences is that a large number of women work only half of the working hours in Germany. In this regard, the European Commission requires better solutions to achieve harmonization between family and work, and to increase the number of women ion leading positions. According to the reports of the European Commission, women employment has been constantly increasing in the past few years. One of three women works part time, while only $8 \%$ of men are employed this way. The employment rate of women with children is $62 \%$, as for men, it amounts to as much as $91 \%$. In the transition countries of Central and Eastern Europe, women have adverse economic status due to the reduced number of employees in the public sector, higher rate of unemployment, greater job insecurity and a poor system of social protection. They are often excluded from the lists of promotion recipients and disrespected within the employment hierarchy. Additionally, they were given undistinguished and lower status functions, and for the most part, denied any real opportunity to show their true talents. Instead, women's role in business world was unjustly marginalized in many countries worldwide and that diminished their capabilities to creatively participate in business decision-making within their companies. To explore these facts, we draw primarily upon our experience while editing a volume of essays entitled "The Perspective of Women's Entrepreneurship in the Age of Globalization" (2007). More specifically, in our research we were concerned with the past and modern processes of economic and social transformation of women role not only in the developing countries but also in the developed and the countries in transition. In this context, it is necessary to stress that the battle for women's rights started back in the late 18th century, which set the stage for the rise of women's movements (Radovic Markovic 2009). Women grew increasingly dissatisfied with the limitations the society had put on their activities. The traditional thinking was the common cliché that a a woman's place was in the kitchen, and that woman's job was to clean the house, look after children, and wash dishes. The generations of women today are definitely more enthusiastic and determined to succeed in pursuing their careers, not having to depend on their male counterparts. Women are not 
only becoming the backbones of families but also the backbones of several companies. A new cliché might be as follows: "in a successful company there is always a woman responsible". In other words, the change towards a more egalitarian society is possible, a change that could fulfil the potentials of all human beings - women and men.

b) Globalization and gender role. Contemporary processes of social transformation are variously identified by such terms as 'neo-liberalism', 'globalization', 'transition', 'information society', ' knowledge-based economy' and 'learning society'. When talking of the impact of globalization upon the transformation of the society in the social, economic and political areas, it is also necessary to define its impact upon the position of the genders. Namely, it is clear that globalization has had a major impact on gender roles. Many critics, however, fear that globalization, in the sense of integration of a country into world society, will cause gender inequality. It may harm women in several ways:

Economically; through discrimination in favour of male workers, marginalization of women in unpaid or informal labour, exploitation of women in lowwage sweatshop settings, and/or impoverishment though loss of traditional sources of income.

$>$ Politically; through exclusion from domestic political process and loss of control to global pressures.

Culturally; through loss of identity and autonomy to a hegemonic global culture.

$>$ On the other side, Janet Mommsen from Kings College and London School of Economics and Political Science stressed in her the latest book ("Gender and Development”, 2004) that globalization gives poor women brighter future. Much of the benefits of globalization for women are more political and social than economic, Mommsen says. She points to a growing confidence and sense of power, as poor women are able to earn more money, feed their children and earn their husbands' respect.

There is an enormous amount of literature on women' employment which was applied to comparative research. It ranges from concepts of patriarchy to debates in human capital and segmented labour market theory. Rubery (1988) argued that application of societal perspective to women' employment means that we need to understand the way in which the system of industrial, labour market and family organization interrelate and the role of the society's political and social values in maintaining these relationships before we could expect to make sense of the differences between the countries in the position of women. The study and similar ones for the most part are blind to take into account many important factors in their research. It is our opinion that the gender roles throughout the world vary due to many factors, and if globalization does anything to change this fact, it would be through the exchange of knowledge. New technologies and the Internet help globalization, and we believe that it helps to lessen the gap between the rich and the poor, however not as much as it could. The Internet allows to spread knowledge much faster than it was possible before. The knowledge allows people to take opportunities they were not in a position to take before. There is now a global interaction with groups of women talking about everything from how to handle domestic violence to how to start small businesses. In other words, it helps to spread the ideas through the world and allows the ideas to be shared and thus allows rich countries to spread the ideas within their own group, leading to global knowledge increase that helps lower the gap between the rich and the poor. Because of globalization, there has been a growing exposure of countries around the world to foreign cultures and peoples. Thus, the most noticeable example of globalization on gender roles can be seen in those countries that look up to the global example and begin to promote national equality where there was once extreme inequality.

c) Gender inequality and entrepreneurship in Europe. In the European enlargement policy gender equality also occupies one of the main areas. Equality of women and men is a common and one of the fundamental values of the EU Member States, ensured in the provisions of the EU Treaty itself, which stipulates the promotion of gender equality as a permanent objective of the European Community in all its activities.

The gender inequality is very pronounced in the field of entrepreneurship in Serbia as well as in the former Yugoslavia countries. According to the data that were published in the study "Women and Men in Serbia" published by the Republic Statistical Office of Serbia, there is an obvious disproportion by gender between the employers and employees. In this regard, the ratio for women is 1 to 2, while for men it is almost 1 to 1 . Also, the number of women employers is less than half of the number of men in the same categories and that relationship in the last five 
years has not changed significantly as the indicator for the lack of supporting female entrepreneurship in Serbia. In Croatia, women constitute $52 \%$ of the total Croatian population, their share in employment being $45 \%$, i.e. $52 \%$ in the public and $39 \%$ in the private sectors. The participation of women in enterprises is $30 \%$, on managerial positions it is $27 \%$, and they amount to only $19 \%$ in the supervisory boards of companies. The rate of women employees in the so-called 'grey' economy is $65 \%$, while the employment rate of female population on the basis of a contract for part time is as high as $86 \%$. In Bosnia and Herzegovina, the rate of women participation in the total number of employees is $43 \%$ which is extremely low compared to the global standard of $52.5 \%$. They usually earn less than men and their role in the enterprise is smaller. Women spend less time in their business than men. More precisely, women entrepreneurs work 29.2 hours per week, while men spend 46.9 hours. In 2007, the female unemployment rate was $32.9 \%$ in comparison with $26.7 \%$ for men. This rate is alarmingly high in the category of young women aged 15 to 24 , where the rate is $63.1 \%$, compared to $55.6 \%$ of men in the same age categories. The biggest obstacles and difficulties for the development of enterprises are located within the availability of financial resources, information, education and markets. The basic challenge is to effectively identify and resolve the problems of the employed through the prioritization of the legislature and other public policies of the countries, and to implement the government measures. Similarly, it is important to develop the national strategy that will effectively confront the problems specific to equal opportunities, which requires the development of other social attitudes about gender and their inclusion in the structures, institutions and policies that relate to self-employment and small enterprise. In the process of promoting and implementing policies of gender equality and empowerment of women, non-governmental organizations and networks play an important role. Their actions and advocacy of public policy affect the public and participate in proposing and solving particular problems. Strengthening civil society is a permanent goal and an imperative prerequisite for the advanced society in the field of women' human rights, which is extremely important for further improvement of cooperation system, coordination and partnership of NGOs with state institutions at both national and local levels. Although in the last few years the EU policy has been oriented towards the establishment of the institutional framework and the promotion of inclusion principles of gender equality in different areas of policy within and outside the Union, it is evident that it is necessary to continue work on the development and strengthening of these institutions and forms for cooperation with a unified activity towards a more effective enforcement of legislation and implementation goals of the EU and national policies.

d) Women and informal employment. When some studies of employment are analyzed, it is necessary to include informal sector of the economy in the analysis too the mentioned sector that was not tackled by Afgan and Carvalho, Natarajan, Nagan (2010).

A large number of studies point out that income disparities increase in the early stages of development, making the poor relatively worse off. Some studies deny the existence of the inverse relation between equality of income and economic growth (Buedo 2002) and some give evidence of the negative impact of inequality and the positive effect of redistribution upon growth (Aghion, Caroli and Garcia-Penalosa 1999). Although it is widely accepted that inequality problems are best solved by fast economic development, the predominant opinion in the modern literature is that, in addition, ignoring inequality in the pursuit of development can be perilous (Jovičić, Milojević 2010). Some authors have argued that inequality has risen further in those countries that actively pursued reforms (see, for example, Milanović 1998). There is also empirical evidence of a significant direct link between the level of income inequality and the share of the informal sector in the economy. Rutkowski (1996) highlighted the fact that excluding the informal sector in the transition countries, where it accounts for a significant part of overall economic activity, it is likely to underestimate the actual level of earnings inequality. Spariosu (2007) concluded that inequality and the growth of the informal economy in the early stage of the transition process can be interpreted as a result of the general decrease of economic activities caused by main transition processes: reallocation and restructuring. However, in our opinion the emergence and the development of the informal economy can be explained partially also as a consequence of the disorganization process.

In addition, three estimation approaches of the informal economy can be distinguished: direct, indirect 
or discrepancy approaches and the model approach. The first two approaches are based on a single factor as the main generator of the informal economy. However, the informal economy is a complex phenomenon simultaneously determined by many factors. Consequently, in the most advanced model approach the multiple causes and indicators are treated simultaneously and explicitly as the determinants of the informal economy.

This sector is especially important for the transition countries as well as the developing countries where more than one third of the labour force is employed in this sector of economy. In the transition economies and in the developing countries, informal work emerges primarily for the existential reasons and the need to survive while in the developed countries it spreads from chances and opportunities though the contribution of women to the informal sector of economy in all the countries is rather marginalized. In the majority of the transition economies, in fact, those employed in the informal sector are not protected by the currently ruling laws.

The high rate of unemployment, low wages and nonpayment of salaries has led to the rapid growth of informal employment. Examples of informal work in Eastern Europe are multiple job holdings that combine employment in the remaining public sector (e.g. teachers and doctors) with other activities because of low purchasing power. The informal economy or residual economy may appear in different forms. It consists of a range of informal enterprises and informal jobs. Jobs in informal sector are at first sight invisible, e.g. hotel jobs, restaurant jobs, jobs in major cities' streets (fruit and vegetables salesmen and saleswomen, refreshing drinks salespersons, etc.).

Here we have in mind primarily the unfavourable conditions of work and long working hours as well as the rewarding system and the pay for the job accomplished. The aid from the society is also missing - there are no special - purpose loans or credits, which further prevent women from implementing their obvious entrepreneurial and managerial potentials. In order to improve the working and living conditions of the informal sector labour force, which does not participate in business decision making (as it includes mainly low-skilled labour force), it is necessary to include them into the processes of education and additional training. The end result should be their inclusion into the formal sector of economy, where they should be entitled to all the legal rights observed in the legal employment.

The gender analysis of the informal economy should not be restricted to the identification of differences between men and women; it involves a group of dimensions that intervene in social relations and from them the adjustments are to be made to the policies and institutions in order to reach fair goals. Still there are many companies that do not acknowledge that women can do a job just as well as men and there are many limiting sexist and chauvinistic views on women running certain businesses. Therefore, in many countries women grew increasingly dissatisfied with the limitations. Major problems with employing women are as follows (Radović Marković 2009b):

$>$ Inadequate qualification structure

$>$ Age discrimination

$>$ Pressures to delay marriage and parenthood

Providing women with increased economic opportunity for employment is critical to the challenges the world economies face.

e) Female entrepreneurship development as an imperative in "new economy". There is no doubt that the progress made by women in entrepreneurship activities worldwide is an important factor to be taken into consideration when studying economic development and social progress. Namely, entrepreneurship represents an appropriate opportunity for women all over the world, as entrepreneurship responds flexibly to entry, change and innovation. It is for this reason that a lot of countries see women entrepreneurs in SMEs as a hope for providing new blood to the economy. At present, women represent more than one third of all people involved in entrepreneurship activities around the world. Different theoretical approaches to female entrepreneurship show that this field of research is considered very broad. According to different theoretical approaches, different perspectives are offered through which we can expand and challenge our understanding of women' entrepreneurship and education. The goal of our work in this area is to offer more ways of encouraging entrepreneurship including the role of education system developing positive attitudes and active approach towards female entrepreneurship. It is well known that there is a correlation between entrepreneurship and economic performance. But entrepreneurship brings more than this correlation to our societies because the science is also a vehicle for personal development. In spite of the importance of entrepre- 
neurship for personal and social development, all potentials are not fully exploited particularly in the European Union (EU). The EU has failed to encourage an enormous number of people to become entrepreneurs. According to the Eurobarometer, although $47 \%$ of the Europeans prefer self-employment, only $17 \%$ actually realize their ambitions (European Commission, 2007). As regards the new entrepreneurial initiative, only $4 \%$ of the Europeans said that they desired to be engaged in setting up business and 29\% of Europe's SME declared growth as their main ambition (EC). Europe, unlike the United States, suffers from low expansion rates after the start-up. As a rule, women all over in the world start businesses in the service sectors which are most attractive to them. For example, women find it much easier to manage companies in the developed countries, while keeping financial stability of business is more difficult in the countries with lower GDP and a "lifetime" of women's enterprises is shorter. According to the age criterion, the usual age of the women who start their own business range from 25 to 34 in less developed countries, and they are not likely to achieve any greater success and respect until they are 35 to 44 years old. In the developed countries the situation is even worse; women choose to start with their own business from age 25 to 44, reaching the climax of their careers only between the ages of 35 and 54 .

f) Education for entrepreneurship. "Entrepreneurship development concerns the development of people's potential as a country's most valuable resource" (Kroon, De Klerk et.al. 2003). The process is an innovative and dynamic technique, which is also an important segment of the economic growth. An entrepreneur is a catalytic agent of change, which generates employment opportunities for others. Therefore, paying attention to improving skills of entrepreneurs and their education is necessary to increase competencies.

Considering the importance of education for entrepreneurs, it has recently become evident that entrepreneurship is one of the fastest growing sciences in today's undergraduate curricula in the United States and worldwide (Radović Marković 2007a).

The 1990s saw the growth of entrepreneurship as a profession within business. In that professional approach the secret benefit of entrepreneurship education lies.It helps decrease the chances of failure by stressing a consistent and proven set of practices. That idea of professionalizing the process of entrepreneurship is the other great commonality across the entire modern entrepreneurship education. ("Entrepreneurial Education", 2009). In the past 3 decades, formal curricula (majors, minors, and certificates) in entrepreneurship have more than quadrupled: from 104 in 1975 to more than 500 in 2006 ("Entrepreneurship in America"). The development of the courses in entrepreneurship has been exponential. The leaders in the field of entrepreneurship education recognized many definitions of how entrepreneurship could and should be taught and much of the performance depends on the level of education involved. In addition, there have been calls for formal education to place a greater emphasis on entrepreneurship training as one way of helping workers cope with the increasing job instability. This 'career option' has been suggested as an alternative to unemployment (ILO, 2002). It can help in absorbing some displaced workers, generate employment for others and reduce the demand on the beleaguered 'employer organizations'.

The proponents of educational technology have stated for years that faculties need to focus more on teaching "21st-century skills", such as problem solving, critical thinking, and collaboration. The 21 st century learners will need to meet the complex demands of the new economy and society in a globalized form (Radović Marković 2006-2007). The workplace of tomorrow will increasingly require 21 st century learners to work in teams, collaborating across companies, communities, and continents. Certain skills cannot be developed solely by simple multiple-choice exams. New education programmes for entrepreneurs must be based on exchanging good practice through studies and networks among strategic partners (researchers, entrepreneurs, financiers, advisors, policymakers, and so forth). To address individual needs of learners, attention must be paid to the adaptability of the curriculum and the learning environment. A worthy institution views quality issues as primary and integral throughout the conceptual design of its education programmes. True quality institutions must govern their curricula, instruction, and support services by policies and standards established to assure future success of the participants (Capogrossi 2002). On many occasions, the assessment and examination vehicles have been evaluative measures of knowledge and competencies of learners measured against learning objectives derived from the needs of the industry and professions. Successful institutions must design their learning objectives to serve the demonstrated needs of the desired student audience. The academic 
and professional needs of the student audience will be at the foundation of the curriculum, and the subject matter objectives will become the focus of quality control process (Capogrossi 2007).

The changes in women's educational and career attainment may have multifaceted characteristics. Women might have increased their enrolment in colleges compared to men; however, women may still differ in terms of the types of subjects in which they are enrolled. A study conducted by the World Bank has recently showed that if women had the same education as men in the field of agriculture, it would increase from $6 \%$ to $22 \%$ in the developing countries (Radović Marković 2007b). This example as well as similar ones invites every rightful reason to focus on further development of educational programs aimed at women, and also to enhance contemporary technologies that will improve e-learning.

Distance learning is becoming increasingly attractive for women as some research studies show. Namely, more than $60 \%$ of those over 25 years of age and female opt for this type of development and education in the world (Radović Marković 2006a). The reason for this lies in the fact that this method of learning offers numerous advantages. Among the most prominent benefits, the following may be pointed out:

a) Flexibility of the learning process (learners study at the time most convenient to them)

b) Achieving better balance between personal and other commitments (they may spend more time at home with their families)

c) Minimizing costs (both time and money savings are made)

d) A deeper sense of self-fulfilment (acquiring relevant and useful knowledge and achieving professional goals).

Furthermore, women at a certain age, over the age typical for learners (18-22 years of age), consider virtual classrooms to minimize the embarrassment and alienation factor (Capogrossi. 2002). Having in mind that due to fast changes in techniques and technology especially in the last decade of the 20th century, new kinds of business and jobs emerged, the need for new knowledge became very clear. Accordingly, everywhere in the world the existing education system is redefined and educational programs that have to relate closely to practice are improved. For that sake, "new schools for entrepreneurs and managers" are founded.They are based on modern programs and courses meant for various groups of businesspeople. Virtual faculties are very popular. They are founded worldwide and allow the connection between businesspeople and business learners and lecturers from all around the world no matter where they actually might reside. Participating in the courses and testing via the Internet, essentially change the previous way of gaining knowledge in usual classrooms. This way of learning contributes to the fast exchange of information, more access to the newest knowledge and experiences in this domain and saves the time and money. Thus, in this millennium, the classic way of education will be slowly substituted by some other forms of education, in which learning from at home and office with the help of computers will be a viable solution. Interactive education should provide a completely new dimension of gaining knowledge making learning faster and easier for those who attend certain courses. It also enables women to choose a certified course, offered by more than $90 \%$ of the faculties in the world (Radović Marković 2007b). Accordingly, women are given the opportunity of choosing some of the programs from a broader range, the ones that suit their professional interests and goals best, without the requirement to move geographically. In other words, women are no longer limited to the local educational institutions but have a more comprehensive choice of educational programs offered worldwide at their disposal. Studying over the Internet ensures women a permanent development thus reducing the educational gap in comparison to men. At the same time, social status and life quality of women are improved. Higher qualifications enable women to contribute more to their community.

g) New modalities of knowledge delivery. Although an increasing importance is assigned to the universities in the field of raising education levels in the new economy (knowledge society)there is a lack of works that research the new forms of knowledge transfer, essential for its development. The Internet has extended many new opportunities to businesspeople, both men and women. One such opportunity is the ability to complete programs online. Most universities, polytechnics, and other training providers are presently using study-away approach capitalizing on the online potentials of the Internet programs delivery as and when services are warranted. The learners increasingly complete a traditional degree and people who want to expand their skill sets are reverting to online programs. The selection is made, partly due to 
convenience and effectiveness and partly due to the fact that the programs are affordable as a whole.

Online programs range from 1-hour courses on selfdevelopment to the entire doctoral degree program. In 2001 ,the American Business Women Association (ABWA), carrying out with its mission to help educate and train members, viewed online classes and course-work as an effective option for women who desire to continue developing their business skills, and hence the association embarked on the creation of more partnerships with quality companies that involved online programs delivery (Radovic Markovic 2009 a). For instance, the association formed partnership with QuicKnowledge.com, which offers discounts on all its courses to the ABWA members. The association also considers all hours completed through online courses as part of its Continuing Education Credit program (ABWA).

However, the most significant contribution of online programs particularly to women is having the opportunity to self-pace within a desired time frame (Radovic Markovic 2009 a). Through the online programs, learners can complete projects whether at work, home, or other selected locations. On many occasions, a busy executive may not be able to leave the office, and yet, assignments, term papers and even research projects have to be finalized somehow; the magic of getting the assignments complete may be made possible through the online mode, where programs are completely in online mode, all class lectures, assignments, tests and instructions are delivered via the Internet. Some programs have a voice and/or video assisted delivery and may also include PowerPoint and iPod presentations. That is the main reason that the Internet service provider, browser, and computer with plenty of random access memory (RAM) are needed prior to an online course commencing to receive lectures from anywhere and anytime.

The implementation of new technologies can substantially reduce training costs (eg., travel,food, and housing) related to bringing geographically dispersed employees to one central training location. These technologies allow trainers to build many of the desirable features of the learning environment into training (Kumpikaite 2008).

\section{Conclusions}

This article critically reviews a range of theoretical approaches to employment research. It shows that conventional theories and practices no longer provide the necessary guidance and support for employment in the world of change, complexity and uncertainty. In that case the move towards a new employment methodology and strategy is necessary in terms of which the employment research will be radically redefined to take holistic approach and emerging realities into consideration. Such holistic and integrated approach has a strongly grounded rationale for support employment theory and practice. Interdisciplinary concepts allow us to extend and raiseing new questions for research. These concepts enable us not only to theorize our research, connecting our own findings with larger conversations but also to reframe theories, so that we see them in new ways and gain new insights. In addition, interdisciplinary research is vital, even essential, the scholars and the researchers must face.

\section{References}

Afgan , N. H.; Carvalho, M. G., 2010. The Knowledge Society: A Sustainability Paradigm, Cadmus, 1(2010):54-65.

American Business Women Association (ABWA).2001. The Advantages of Online Learning, Women in Business, 53(6): 23-23.

Aghion, P.; Caroli, E.; Garcia-Penalosa,C.1999. Inequality and Economic Growth: The Perspective of the New Growth Theories, Journal of Economic Literature, 37(4): 1615-1660.

Buedo, J, 2002. The Trade- off between Efficiency and Equality: The Role of a Changing Economic Idea in the Political Strategy of the Social Democracy, EUI Working paper 5.European Union Institute, Florence

Capogrossi, D. 2002. Assurance of Academic Excellence among Nontraditional Universities, Journal of Higher Education in Europe, 27(4): 481-490.

Capogrossi, D. 2007. Four keys for personalizing distance learning, in "Gender and informal economy: Developing developed and transition countries". ICEA and PRENTICECONSULTS, Lagos, 2007.

Entrepreneurial education, 2009. Retrieved January 30, 2009. Available on the Internet: <http:// en.wikipedia.org/wiki/Entrepreneurship_education> 
Entrepreneurship in American higher education. A report from the Kauffman Panel on Entrepreneurship Curriculum In Higher Education, 2006. Retrieved January 30, 2009. Available on the Internet: <http:// www.kauffman.org/uploadedfiles/entrep_high_ed_ report.pdf>

European Commission (EC), 2007.Euro barometer. Retrieved February 10, 2009. Available on the Internet:

<http://ec.europa.eu/growthandjobs/europeandimension/200812-annualprogress-report/index_ en.htm>

Earnings Inequality and the Informal Economy Evidence from Serbia, 2010. European Bank for Reconstruction and Development. Available on the Internet: <http://www.ebrd.com/pubs.econo/wp0114.pdf>

Ivančev O.; Jovičić M.; Milojević T.,2010.Poverty and Inequality Changes in Serbia as the Result of Global Instability. Available on the Internet: <http://balkan-observatory.net/wp/2010\%2010\%20wiiw\%20 bo\%20wp\%20086.pdf>

Kroon, J.; De Klerk, S.; Dippenaar, A. K., 2003. Developing the Next Generation of Potential Entrepreneurs: Co-operation between Schools and Businesses, South African Journal of Education, 23(4): 319-322.

Kumpikaite, V. 2008. Human resource Development in Learning Organization, Journal of Business Economics and Management, Vilnius, 2008, (9)1:25-33.

Milanovic, B. 1998. Explaining the Increase in Inequality during Transition. Policy, Research Working Paper Series 1935. The World Bank, Washington D.C.

Momsen, J. H. 2004. Gender and Development. Routledge, London and New York.

Nagan, W. 2010 .Human Rights and Employment, Cadmus, 1(2010):64-69.

Natarajan, A. 2010.Theory and Strategies for Full Employment, Cadmus, 1(2010):24-36

Radović Marković, M. 2010. Country Note: Serbia. OECD, Paris.

Radovic Markovic, M. 2009 .Education through E-learning: Case of Serbia, Journal of Business Economics and Management, 4 (2009): 313-319.

Radović Marković, M. 2009b. Globalization and
Gender Participation in the Informal Sector in Developing and Transitional Countries, E+M (Economics and Management Journal), Technical University of Liberec in cooperation with other universities in the Czech Republic and Slovakia, 4(2009): 6-16.

Radović Marković, M. 2007b. Special Benefits of E-learning for Women: Sample of Program Entrepreneurship in "Gender and Informal Economy: Developing Developed and Transition Countries". ICEA and PRENTICECONSULT, Lagos.

Radović Marković, M. 2006b. Women Entrepreneurs and Managers in Serbia. Retrieved March 272009. Available on the Internet: http://www.ien.bg.ac.yu/ download/wp06-4.pdf

Radović Marković, M.; Porter, N. B.; Omolaja, M. 2009 a. The New Alternative Women's Entrepreneurship Education: E-Learning and Virtual Universities, Journal of Women's Entrepreneurship and Education, 1-2(2009a):1-12.

Rubery, J. 1988 .Women and Recession: a Comparative Perspective.Routledge \& Kegan Paul, London.

Rutkowski, J. 1996. Changes in the wage structure during economic transition in central and Eastern Europe. World Bank technical paper 340, World Bank Group, Washington.

Spariosu, T. 2007. Hidden Economy in OECD and Transition Countries in "Gender and Informal Economy in Developing, Developed and Transition Countries. ICEA \& PRENTICECONSULT, Lagos. 